\title{
Sponge species composition, abundance, and cover in marine lakes and coastal mangroves in Berau, Indonesia
}

\author{
Leontine E. Becking ${ }^{1,2, *}$, Daniel F. R. Cleary ${ }^{3}$, Nicole J. de Voogd ${ }^{1}$ \\ ${ }^{1}$ Naturalis Biodiversity Center, Department Marine Zoology, PO Box 9517, 2300 RA Leiden, The Netherlands \\ ${ }^{2}$ Institute for Marine Resources and Ecosystem Studies, PO Box 57, 1780 AB Den Helder, The Netherlands \\ ${ }^{3}$ Centre for Environmental and Marine Studies, Department of Biology, University of Aveiro, 3810-193 Aveiro, Portugal
}

\begin{abstract}
We compared the species composition, abundance, and cover of sponges in 2 marine lakes (Kakaban Lake and Haji Buang Lake) and adjacent coastal mangroves on the islands of Kakaban and Maratua in the Berau region of Indonesia. We recorded a total of 115 sponge species, 33 of which were restricted to Kakaban Lake, 18 to Haji Buang Lake, and 30 to coastal mangroves on Maratua Island. Only 13 species were shared among all habitats. The 2 marine lakes are located $10 \mathrm{~km}$ apart, but their assemblages were more similar to each other than to the bay mangrove systems just 200 to $500 \mathrm{~m}$ away. Our results show that marine lakes represent a distinct habitat with significantly higher sponge cover and abundance as well as a markedly different species composition when compared with coastal mangroves. In both lake and coastal mangrove habitats there was a pronounced gradient in composition away from the shore with the primary difference between solid (root or rock) and soft substrate (mud or sand). Each substrate type harbored different sets of species in both lake and coastal mangrove habitats. There was no significant difference in sponge species composition, abundance, or cover between semi-permanent transects sampled in 2008 and 2009. We show for the first time that mangroves in the Indo-Pacific harbor a diverse array of sponge species and, further, that marine lakes harbor numerous unique species hitherto unknown to science.
\end{abstract}

KEY WORDS: Mangrove roots - Species assemblage - Principal coordinates analysis - Borneo · East Kalimantan · Kakaban · Anchialine systems

\section{INTRODUCTION}

Mangrove forests grow pantropically on protected coasts and can host diverse colorful assemblages of epibionts (Farnsworth \& Ellison 1996, Diaz et al. 2004). The vast majority of mangrove-epibiont studies have been conducted in the Caribbean where sponges, together with algae, cnidarians, and ascidians, are the most dominant taxa covering mangrove roots (e.g. Ellison et al. 1996, Farnsworth \& Ellison 1996, Diaz 2005). There is a facultative mutualism between sponges and the mangroves: mangroves provide the only hard substrate for sponges in this ecosystem, and passively leak carbon from their roots, which is assimilated by sponges, while sponges directly protect mangrove roots from isopod attack and enhance cable root growth by inducing adventitious rootlet formation (Ellison et al. 1996). Sponge communities in Caribbean mangrove systems are spatially heterogeneous, whereby a species can dominate one site, and be absent from another (Farnsworth \& Ellison 1996, Diaz et al. 2004, Hunting et al. 2008, Guerra-Castro et al. 2011). Sponge communities in mangroves are, furthermore, distinct from those in reefs and contain species that appear to be specifically adapted to survive extremes in salinity, 
temperature, and sedimentation (Rützler 1995, Wulff 2000, 2005, Engel \& Pawlik 2005, Pawlik et al. 2007, Nagelkerken et al. 2008). Biotic factors such as predation and competition for space with other marine invertebrates probably limit their distribution in coral reefs (Aerts \& van Soest 1997, Wulff 2000, 2005, de Voogd et al. 2004, Nagelkerken et al. 2008). Competition for space in the mangroves is, however, also intense as there is limited hard substrate, which most sponges require for survival. This favors species with high growth rates and the production of possible allelochemicals to ward off spatial competitors (Engel \& Pawlik 2005, Wulff 2005, 2010, Nagelkerken et al. 2008). The composition of these epibiont communities can either be seasonally dynamic (such as in Florida and Jamaica) or be stable over longer time periods (such as in Belize and Venezuela) (Sutherland 1980, Bingham \& Young 1995, Farnsworth \& Ellison 1996, Wulff 2004, Pawlik et al. 2007).

Indonesia contains the most diverse mangrove ecosystems in the world, covering an area of almost $50000 \mathrm{~km}^{2}$ (Spalding et al. 1997, Alongi 2002), but to date there have been no comprehensive studies of mangrove epibionts. A recent review of the habitat function of mangroves for terrestrial and marine fauna suggested that the mangrove systems in the IndoPacific may not have the high diversity of sponges found in the Caribbean (Nagelkerken et al. 2008). In East African mangroves only 3 sponge species were found (Barnes 1999) and in 2 surveys of the faunal diversity in mangroves in the Indian Ocean and Malaysia not a single sponge species was recorded on mangrove roots (Rützler 1964, Sasekumar \& Chong 1998). These 3 publications are, however, the only published studies of sponges and mangroves in the Indo-Pacific, compared with more than 40 for the Caribbean. In Indonesia, mangroves occur along coasts and, in contrast to the Caribbean, within marine lakes (Becking et al. 2011). Marine lakes are anchialine systems - small bodies of landlocked seawater isolated to varying degrees from the surrounding marine environment (Holthuis 1973, Hamner \& Hamner 1998, Colin 2009, Becking et al. 2011). The marine character of these systems is maintained by subterranean tunnels, fissures, or small dissolution channels in the surrounding rock, connecting the lakes to the adjacent sea, and as such display a wide variety in the degree of connection to the sea and environmental regimes within the lakes (Hamner \& Hamner 1998, Cerrano et al. 2006, Azzini et al. 2007, Becking et al. 2011). The total number of marine lakes worldwide is estimated at only 200 with clusters of 10 or more lakes occurring in areas with a karstic limestone landscape such as Croatia, Bermuda, Vietnam, Palau, and Indonesia (Dawson et al. 2009). Preliminary surveys of macrobiota in marine lakes in Indonesia, Vietnam, and Palau have shown that sponges, algae, ascidians, and mollusks are the most dominant taxa in terms of abundance and diversity (Hoeksema 2004, Cerrano et al. 2006, Colin 2009, Becking et al. 2011). This enclosed environment has set the stage for small, isolated, rapidly evolving populations, and possibly endemic (sub)species (Holthuis 1973, Maciolek 1983, Tomascik \& Mah 1994, Fransen \& Tomascik 1996, Massin \& Tomascik 1996, Dawson \& Hamner 2005).

This study is the first comprehensive assessment of sponges in marine lakes and mangroves in Indonesia. Our aim was to quantify spatial variation in the abundance and species composition of sponges in marine lakes and adjacent coastal mangrove systems in the Berau region of Indonesia. We related spatial variation in composition to the habitat (marine lake or coastal mangrove), substrate, and sampling event. Our objectives were to: (1) assess whether sponge composition in the marine lakes is distinct from that in the outer coastal mangroves; (2) identify species that are unique to each major habitat; and (3) relate variation in sponge abundance, cover, and species composition to substrate type and cover of other sessile biota.

\section{MATERIALS AND METHODS}

\section{Study area}

We surveyed marine lakes and coastal mangrove systems on the islands of Kakaban and Maratua in the Berau region, East Kalimantan province, Indonesia (Fig. 1). These islands fall within the Berau marine protected area and provide a setting to survey sponge assemblages at varying scales ( $\mathrm{m}$ to $\mathrm{km}$ ) in marine lakes and coastal mangroves (Tomascik et al. 1997, Becking et al. 2011). The annual rainfall in Berau is approximately $2000 \mathrm{~mm}$ with no pronounced rainy season, though there is less rainfall from June to September (average 110 to $125 \mathrm{~mm}$ per month) compared with the rest of the year (average 150 to $200 \mathrm{~mm}$ per month) and an increase of strong winds from the north between December and March (Tomascik et al. 1997, Mantel 2001, Renema 2006).

A general description of the lakes of Kakaban and Maratua is provided by Tomascik \& Mah (1994), Tomascik et al. (1997) and Becking et al. (2011). Kakaban Island is a trapezoidal-shaped island with a protected southern coast fringed by mangroves, of 

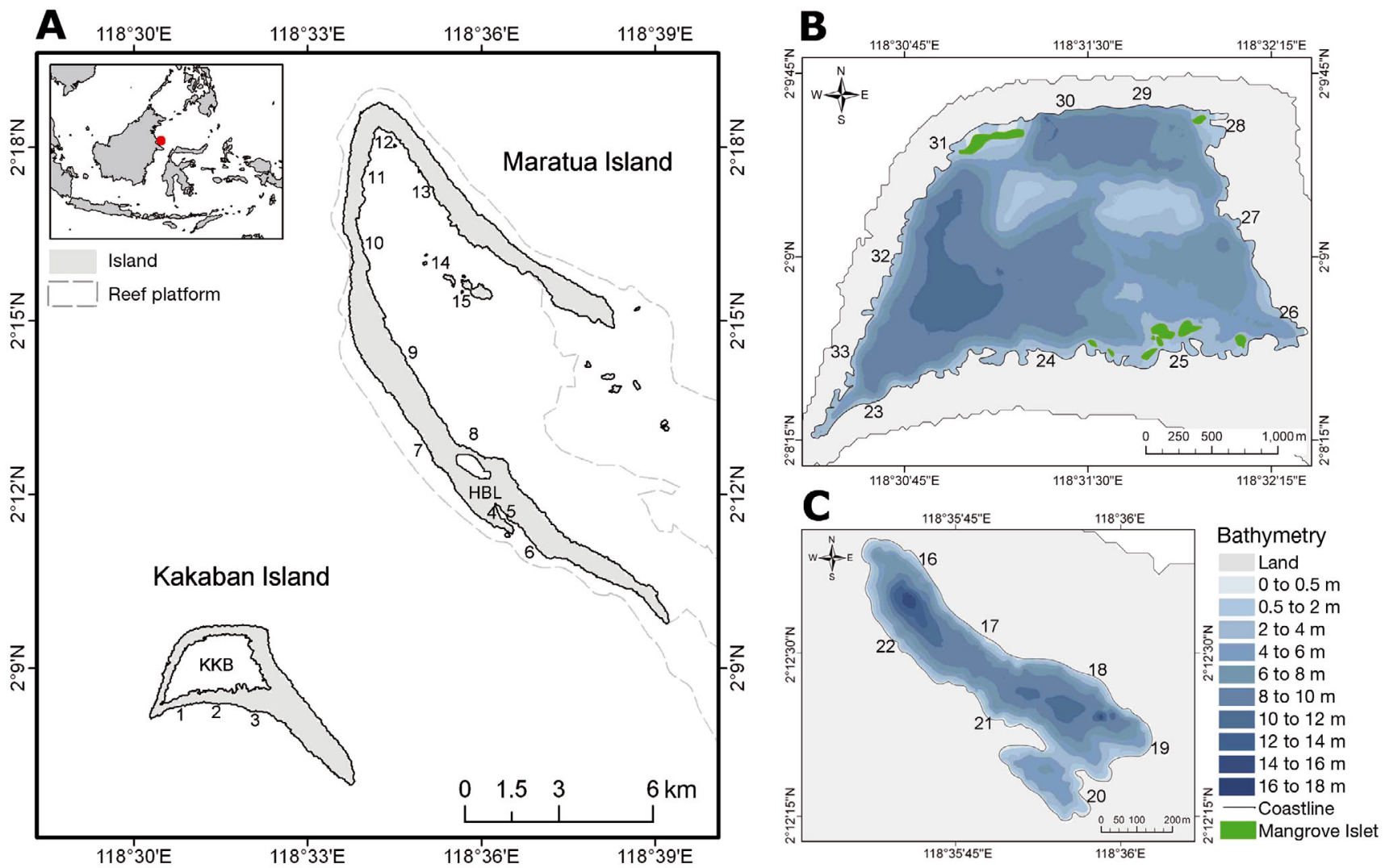

Fig. 1. (A) Map of Kakaban and Maratua islands in Berau region, East Kalimantan province, Indonesia. Bathymetric maps of (B) Kakaban Lake and (C) Haji Buang Lake. Note different scales in B and C. Sample site locations indicated with numbers 1 to 33 . Sites $1,2,3,6,7,10,11,12$, and 14 in coastal mangrove systems contained no sponge epibionts

which Avicennia marina is the most conspicuous with aerial roots exposed to air at low tide. In the centre of Kakaban Island is a large, approximately $4 \mathrm{~km}^{2}$, marine lake with the southern, western, and eastern shores fringed by mangroves dominated by Bruguiera gymnorrhiza, of which the roots are submerged (Fig. 2A); the northern shore is predominantly rocky. The dominant algae in this lake are species of the genus Halimeda. Bathymetric surveys revealed that Kakaban Lake averages $8 \mathrm{~m}$ depth, with a $12 \mathrm{~m}$ deep depression at the western portion of the lake (Fig. 1B). The tidal amplitude in Kakaban Lake $(19 \mathrm{~cm})$ is dampened to $9.5 \%$ of adjacent sea amplitude $(200 \mathrm{~cm})$; the tidal phase has a delay of $3 \mathrm{~h}$ 30 min compared with the surrounding sea, indicating that there is little connection between the lake and the sea (Becking et al. 2011).

Maratua is a horseshoe-shaped island with a large bay that partly encloses a large lagoon of approximately $29.5 \times 6.5 \mathrm{~km}$ with a depth of 0.5 to $5.0 \mathrm{~m}$ at low tide. Parts of the bay are rimmed by patches of Avicennia marina, Sonneratia alba, and Rhizophora mucronata mangroves with aerial- or proproots ex- posed to air at low tide (Fig. 2B). The mangrove transitions to a sandy reef flat away from the coast. On Maratua Island there are at least 9 anchialine systems, of which Haji Buang Lake is the largest marine lake (Fig. 2C). Haji Buang Lake is an elongated lake of $0.14 \mathrm{~km}^{2}$ surface area located on the western arm of Maratua. Haji Buang Lake averages $10 \mathrm{~m}$ depth, with 2 deep depressions at the northern $(19 \mathrm{~m})$ and southern $(15 \mathrm{~m})$ ends of the lake (Fig. 1C). The largest part of the lake's coastline is formed by limestone rock (Fig. 2D) with only a small patch of the southern coast fringed by mangroves (predominantly Bruguiera gymnorrhiza) with a seagrass field (Enhalus sp.) in front. The dominant algae in this lake are species of the genus Caulerpa. The tidal amplitude in the lake $(90 \mathrm{~cm})$ is dampened to $45 \%$ of the adjacent sea amplitude $(200 \mathrm{~cm})$ and the tidal phase has a delay of $2 \mathrm{~h} 30$ min (Becking et al. 2011), indicating that the connection to the sea is limited, but higher than in Kakaban Lake.

Coastal mangroves were patchy along the coasts of Maratua and Kakaban islands. In addition to this, sponge abundance varied greatly within the man- 

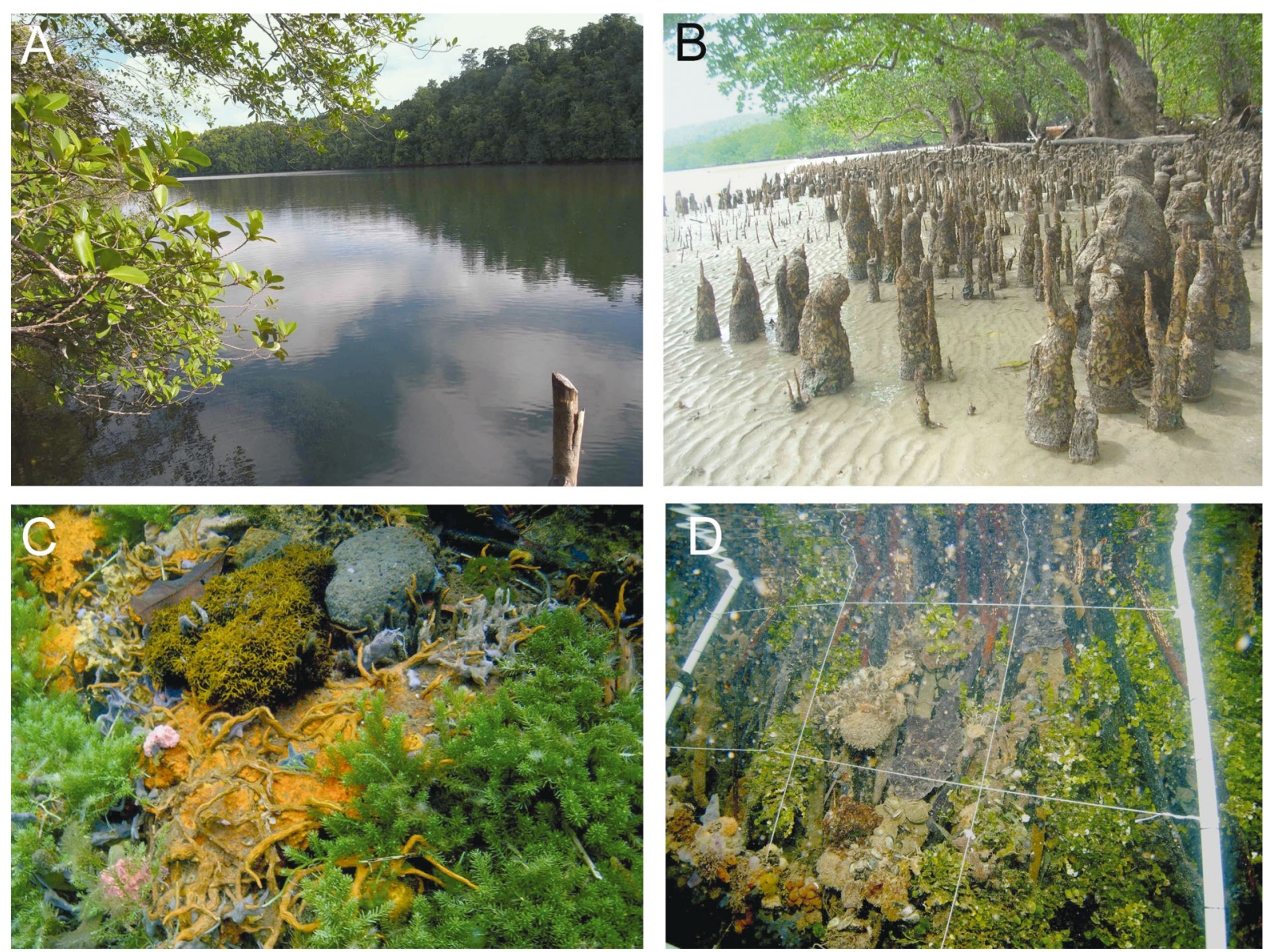

Fig. 2. The 2 habitats (marine lakes and outer coastal mangroves) in Berau, East Kalimantan, Indonesia. (A) Haji Buang Lake. (B) Coastal mangrove in Maratua Bay with roots fully exposed to air and sun at low tide. (C) Sponge and algae cover on rocky substrate in Haji Buang Lake. (D) 'Root-wall' and quadrat in mangroves of Kakaban Lake

groves; a number of locations along the coast of Maratua and Kakaban did not contain a single sponge. Transects were laid down randomly along the coast; in 9 sites out of 15 no sponges were recorded (Fig. 1).

\section{Data collection}

Study sites were randomly distributed within Kakaban Lake (KKB), Haji Buang Lake (HBL), and the coastal mangroves of Kakaban and Maratua islands (BAY) (Figs. 1 \& 2); within each site 3 transects were surveyed (Fig. 3). To gain some preliminary knowledge about sponge community dynamics, we recorded data in semi-permanent transects twice within a 1 yr period: between 30 August-20 September 2008 and between 10-31 May 2009. The location of each transect was marked with biodegradable red tape and the coordinates were located with a handheld GPS (Garmin GPS60) with $5 \mathrm{~m}$ variation. The roots of the mangroves in the lakes were so intertwined and meshed that they created a wall-like structure (Fig. 2D), which hindered us from using the more common method of quantifying mangrove epibiont species richness and diversity by haphazardly selecting roots along a transect (e.g. Ellison \& Farnsworth 1992, Farnsworth \& Ellison 1996, Hunting et al. 2008). An alternative method was thus devised to quantify epibiont species abundance and composition on these 'root walls' that enabled a consistent comparison with the variety of substrates that occur in the lakes and the coastal mangroves (e.g. rock-wall, sand, reef flat): a $15 \mathrm{~m}$ transect was placed along the shore and three $1 \mathrm{~m}^{2}$ quadrats were surveyed at the $1 \mathrm{~m}, 10 \mathrm{~m}$, and $15 \mathrm{~m}$ mark; this was repeated 3 times away from the shore to determine whether there was a zonation in species composition with distance from shore (Fig. 3). Zone A quadrats were on the shore within the tidal zone, zone B quadrats were $1 \mathrm{~m}$ offshore, following the contour of the bottom or directly 
Fig. 3. The experimental set-up. A $15 \mathrm{~m}$ transect line was placed along the shore. Squares represent $1 \times 1 \mathrm{~m}$ quadrats that were placed along the transect and away from shore. Not to scale. ${ }^{*}$ Zone B was inter tidal in coastal bay mangrove habitat

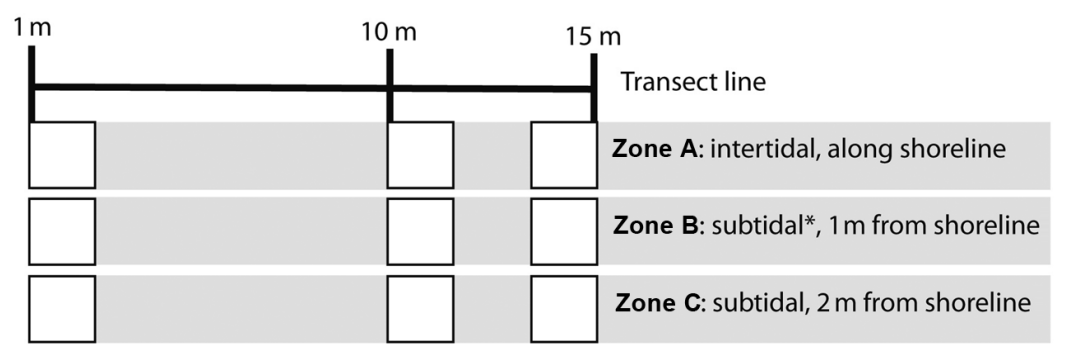

in front of the mangrove roots, and zone $\mathrm{C}$ quadrats were $2 \mathrm{~m}$ offshore, following the contour of the bottom. The quadrats in zone A were fully exposed to air at low tides in the coastal bay mangrove systems, were mostly ( 75 to $90 \%$ ) exposed to air in HBL, and were only partially (5 to $10 \%$ ) exposed to air in KKB. The maximum depth of the quadrat was recorded, as well as the general substrate within the quadrat (root, rock, root and rock, sand, mud). The percentage cover within the quadrat was measured visually with the aid of $33 \times 33 \mathrm{~cm}$ subdivisions of the quadrat. The following categories of cover were recorded: algae, ascidians, coral, mud, mussels, rock, root, sand, seagrass, and sponges. These classes of higher taxonomic groups of associated organisms were selected based on preliminary data that showed that these groups were abundant in marine lakes (Hoeksema 2004, Cerrano et al. 2006, Colin 2009, Becking et al. 2011) and potentially may affect the species composition, abundance and cover of sponges. Subsequently, sponge species and their abundance (number of individuals per species) were recorded within the $1 \mathrm{~m}^{2}$ quadrats. Only sponge individuals larger than $1 \mathrm{~cm}^{2}$ were included in our study and only those that were visible within the quadrat (i.e. individuals behind 'root walls' were not included). We also recorded which species were exposed to air at low tide.

Sponge species were visually identified in the field. In situ and ex situ photographs of each sponge were taken, together with ecological data, and a general morphological description of each specimen following the protocol of Boury-Esnault \& Rützler (1997). For all species, 2 or more vouchers were collected for closer examination of skeletal structure for taxonomic identification. Sponges were identified based on spicule characters, when present, and skeletal structure, then preserved in $70 \%$ ethanol and deposited in the Porifera collection of the Naturalis Biodiversity Center (catalogued as RMNH POR). Ideally, the specimens were identified to species level, however many of the surveyed sponges belonged to novel or little known species and rare genera, so these were assigned to morphospecies awaiting formal description. These morphospecies functioned as operational taxonomic units (irrespective of whether the taxa are recognized within the Linnaean classification), to enable unequivocal comparison across all collections. At present, these morphological hypotheses are being tested and supported by independent molecular datasets in the Sponge Barcoding Project (see www.spongebarcoding.org). Some sponges consisted of a species complex and could not be separated visually in the field; these were grouped together, such as Placospongia spp. (consisted of $P$. carinata, P. melobesioides and P. mixta; Becking in press) and Cinachyrella spp. (consisted of C. porosa, C. australiensis, C. paterifera; Szitenberg et al. 2013).

Salinity, temperature, and $\mathrm{pH}$ were measured twice in each location at each transect in both sampling periods with a handheld multimeter (YSI63-50). Where possible, measurements were made at the surface, and 1 and $2 \mathrm{~m}$ depth.

\section{Data analysis}

\section{Sponge composition}

Data matrices of species abundance per transect were $\log _{10}(x+1)$ transformed and distance matrices constructed using the Bray-Curtis index with the vegdist function in the vegan package in $\mathrm{R}$ (Oksanen et al. 2009). The Bray-Curtis index is one of the most frequently applied (dis)similarity indices used in ecology (Legendre \& Gallagher 2001, Cleary 2003, Cleary et al. 2005, de Voogd et al. 2006). Matrices were constructed for (1) all transects and (2) all transects within each location (KKB, HBL, and BAY) separately. Transects with 5 or fewer individuals (24 out of 153 transects) were removed before analysis. Of the 15 transects dropped, 12 were in Kakaban and 3 in Maratua; 14 of these transects were on a mud substrate and one on a rock substrate. After removal, 60,33 , and 36 transects from KKB, HBL, and BAY, respectively, remained. Variation in sponge species 
composition among location class groups (KKB-mud, KKB-root, KKB-rock, HBL-mud, HBL-root, HBL-rock, BAY-reef, BAY-root, BAY-sand) and sample year was assessed with principal coordinates analysis (PCO) using the cmdscale function in R with the Bray-Curtis distance matrix as input. Variation among location and year was tested for significance using the adonis function in vegan. In the adonis analysis, the BrayCurtis distance matrix of species composition was the response variable with location and sample year as independent variables. We also included the interaction term between location and year. The number of permutations was set at 999; all other arguments used the default values set in the function. For the analyses within each habitat, we followed the above analytical approach but used the adonis analysis to test for significant variation among substrate types (mud, rock and root for KKB and HBL; reef, rock and root for BAY) and sample year. We also included the interaction term between substrate and year. The adonis function is an analysis of variance with distance matrices using permutations that partition distance matrices among sources of variation. In addition to the above, we also tested for associations between species composition and sample depth, and measured substrate class variables, namely the percentage cover of mussels, algae, soft substrate (mud and sand), rock, mangrove roots, seagrass, ascidians, corals, and sponges. These were fitted onto PCO ordinations of each habitat with the envfit function in vegan. Using the envfit function, we also tested for significant relationships between these variables and PCO ordinations of sponge composition using 999 permutations; all other arguments in the function were left as default. The contribution of sponge species to the ordinations was assessed using weighted averages scores for the first 2 axes of each ordination with the wascores function in the vegan package. Detailed descriptions of the functions used can be found in $\mathrm{R}$ (e.g. by typing ?cmdscale) and online in the reference manuals (e.g. http://cran.r-project.org/ web/packages/vegan/index.html).

In addition to environment and time, spatial processes may also play an important role in structuring assemblages. We tested for an effect of space on species composition using principal coordinates of neighbor matrices (PCNM) - a novel method for quantifying spatial trends across a range of scales. PCNM is based on eigenvalue decomposition of a truncated matrix of geographic distances among sampling sites (Borcard \& Legendre 2002, Dray et al. 2006). Significant PCNM eigenvectors were selected using the PCNM function with 999 permutations in the PCNM package in R. Additional arguments for the PCNM function included Hellinger-transformed matrices of species abundance and distance matrices (longitude, latitude); analyses were run for each location (KKB, HBL, and BAY) separately. The forward selection test used was based on a novel forward selection procedure that corrects for the innate type I error and overestimation of explained variance associated with classical forward selection (Blanchet et al. 2008). The PCNM function is available in the vegan package.

Sponge abundance and cover

After testing for normality with the shapiro.test function in $\mathrm{R}$ (all tests deviated significantly ( $\mathrm{p}<$ 0.001) from a normal distribution), we tested for significant differences in sponge abundance and cover at the transect level among substrate type (mud, rock, and root for KKB and HBL, and reef, rock, and root for BAY) and sampling year within locations (KKB, HBL, and BAY) using an adonis analysis in vegan (Oksanen et al. 2009). In the adonis analysis, the Euclidean distance matrix of sponge abundance or sponge cover was the response variable with substrate type and sample year (2008 or 2009) as independent variables. We also included the interaction term between substrate type and depth. The number of permutations was set at 999; all other arguments used the default values set in the function.

\section{RESULTS}

A list of species found is given in Table 1. Salinity, temperature, and $\mathrm{pH}$ were similar between sampling periods and between sites within a location. The range of environmental variables per location is given in Table 2. A total of 9 sites in the outer coastal mangrove system did not contain epibionts: Sites 1-3 (on Kakaban Island), and Sites 6, 7, 10, 11, 12, and 14 (on Maratua Island) (Fig. 1A). These were not included in the analyses.

\section{Sponge composition}

We recorded 10167 sponge individuals, belonging to 115 species, 10 orders, 32 families, and 52 genera (Table 1). A total of 67 species were recorded in $\mathrm{KKB}$, 53 species in HBL, and 47 in BAY. A total of 33 species were restricted to $\mathrm{KKB}, 18$ to $\mathrm{HBL}$, and 30 to 
Table 1. Recorded species in marine lakes and mangroves in East Kalimantan, Indonesia. The majority of marine lake species are undescribed, therefore many species are denoted with 'sp.' or 'aff.', and the descriptors in single quote marks are only meant as simple descriptors and do not have any taxonomic value. Also given are the species codes used in Figs. 4 \& 5, whether a species was recorded exposed to air (Exp.), the occurrence on substrate type (root rock, sand, mud, reef), and the occurrence in the 3 locations of this study Kakaban Lake (KKB), Haji Buang Lake (HBL), and the outer coastal mangroves of Maratua Island (BAY)

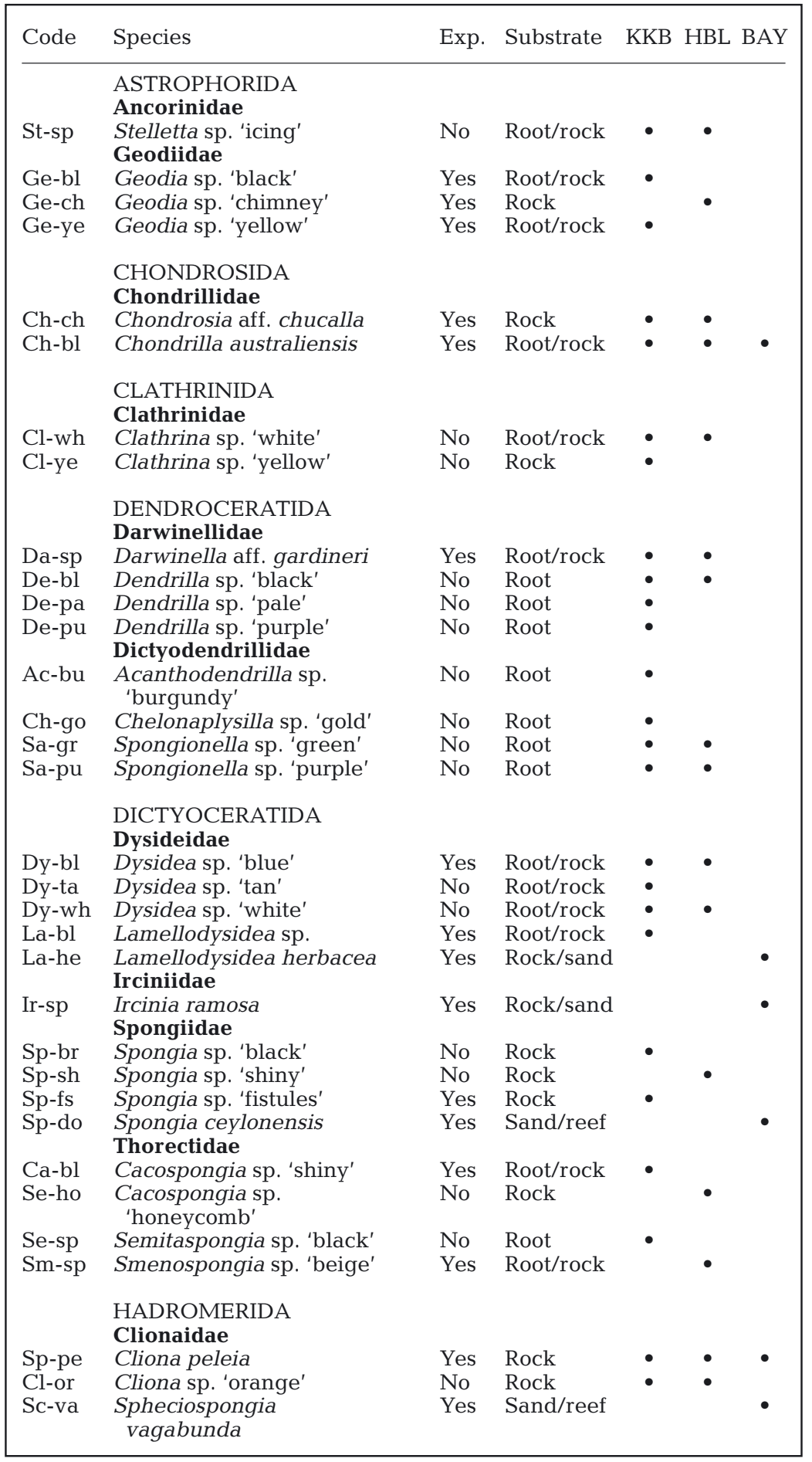

(continued on next page)
BAY. The 2 lakes (KKB and HBL) shared 18 species; only 13 species were recorded across all 3 locations. Lake habitat (KKB and HBL combined) harbored 85 species, 16 of which were shared with the coastal bay mangrove habitat (Table 1).

Sponge species composition differed significantly among locations, but not between years (Fig. 4). There was also no significant interaction between location and year. Each location formed a distinct cluster (Fig. 4A), but the 2 lakes were clearly more similar to one another than to the coastal mangroves and shared many more species than either lake shared with the BAY habitat (Fig. 4B). The lake transects on a mud substrate resembled the coastal bay transects more closely than the other transects (Fig. 4). There was also some temporal variation in species composition as indicated by the vectors, particularly in lake habitats, although this differed among transects (Fig. 4).

In all 3 locations, there was a significant difference in species composition among substrate types, but no significant difference between years (Fig. 5). There was also no significant interaction between habitat and year. There was also no significant effect of spatial processes on species composition based on results of the PCNM analyses (all $\mathrm{p}>0.10$ ).

In $\mathrm{KKB}$, the main gradient in composition was related to variation between transects on a mud substrate at greater depth and transects on a hard substrate with high mussel and ascidian cover (Fig. 5A,B). Species associated with a mud substrate include Raspailia aff. clathrata, and Biemna fortis (Fig. 5C,D). Species strongly associated with a rock substrate included Semitaspongia sp., Cliona peleia, Antho ridleyi, and Tethytimea aff. tylota. Species strongly associated with a root substrate included Spongionella sp. 'green' and Haliclona spp. In BAY, the main gradient in composition was related to variation from transects on a root substrate in shallow water to transects in deeper water on a sand or reef substrate (Fig. 5E,F). Species mainly associated with a root substrate included 
Table 1 (continued)

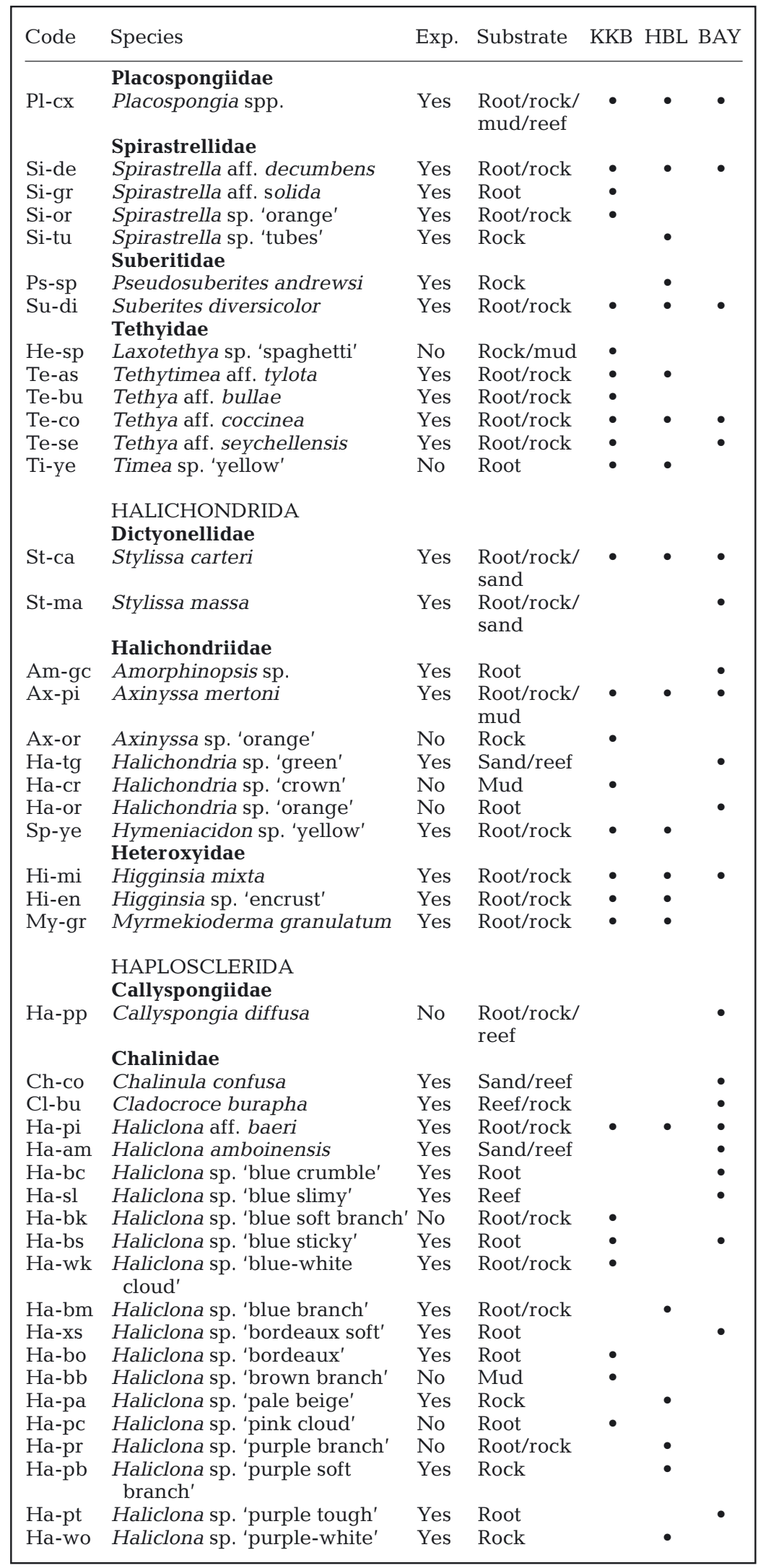

(continued on next page)
Tethya aff. coccinea, Haliclona spp., and Amorphinopsis sp. There was a secondary gradient related to transects with higher coral cover versus transects with higher sand and rock cover. Species more strongly associated with higher coral cover included Placospongia spp., Iotrochota baculifera, and Amphimedon paraviridis, whereas species more strongly associated with higher sand and rock cover included Axinyssa mertoni, Biemna fortis, Cliona peleia, and Cinachyrella spp.

\section{Sponge abundance and cover}

Sponge abundance differed significantly among substrate types in the marine lake habitat, but not in the coastal bay mangrove habitat (Fig. 6, Table 3). Sponge cover also differed significantly among substrate types in the marine lake habitat, but again not in the coastal bay mangrove habitat. Sponge abundance and cover was highest on root and rock substrates in the marine lake habitat and was lowest on mud substrate. There was no significant difference in abundance or cover between years in any habitat nor were there significant interactions between habitat and year (Fig. 6, Table 3).

\section{DISCUSSION}

\section{Differences between habitats}

Marine lakes are true sponge gardens containing distinct assemblages of sponge species. The lakes displayed a markedly higher abundance and cover of sponges compared with the outer coastal mangrove habitat (Figs. 2 \& 5). Transects in the lakes could harbor great densities of sponges with over 200 individuals in an area of only $3 \mathrm{~m}^{2}$, occupying at times up to $100 \%$ of available substrate. These abundances are comparable to the amounts recorded in areas 10 times as large $\left(30 \mathrm{~m}^{2}\right)$ in the adjacent reefs in Berau (de Voogd et al. 2009). 
Table 1 (continued)

\begin{tabular}{|c|c|c|c|c|c|c|}
\hline Code & Species & Exp. & Substrate & KKB & HBL & BAY \\
\hline Ha-py & Haliclona sp. 'purple-yellow' & No & Root/rock & $\bullet$ & & \\
\hline Ha-sp & Haliclona sp. 'soft spikes' & No & Root/rock & • & - & \\
\hline Ha-k2 & Haliclona sp. 'spicky' & No & Rock & $\bullet$ & & \\
\hline Ha-vb & Haliclona sp. 'violet branch' & No & Root/rock & $\bullet$ & & \\
\hline Ha-vc & Haliclona sp. 'violet cloud' & No & Root/rock & $\bullet$ & • & \\
\hline Ha-vs & Haliclona sp. 'violet soft' & Yes & Root/rock & & - & \\
\hline Ha-vt & Haliclona sp. 'violet tube' & Yes & Root & $\bullet$ & & \\
\hline Ha-vv & Haliclona sp. 'violet vase' & Yes & Root & & $\bullet$ & \\
\hline Ha-wm & Haliclona sp. 'white cloud' & No & Root/rock & & $\bullet$ & \\
\hline Ha-we & Haliclona sp. 'white extentions' & Yes & Root/rock & - & & \\
\hline Ha-rh & Haliclona sp. 'yellow branch' & Yes & Root/rock & $\bullet$ & $\bullet$ & \\
\hline Ha-ym & Haliclona sp. 'yellow cloud' & Yes & Root/rock & & - & \\
\hline Ha-yk & Haliclona sp. 'yellow' & Yes & Root/rock & $\bullet$ & & \\
\hline Ha-lo & $\begin{array}{l}\text { Haliclona sp.' white' } \\
\text { Niphatidae }\end{array}$ & No & Root/sand & & & $\bullet$ \\
\hline Am-br & $\begin{array}{l}\text { Amphimedon aff. } \\
\text { queenslandica }\end{array}$ & Yes & $\begin{array}{l}\text { Root/rock/ } \\
\text { sand }\end{array}$ & & & $\bullet$ \\
\hline Am-pa & Amphimedon paraviridis & No & Reef & & & $\bullet$ \\
\hline Am-gr & $\begin{array}{l}\text { Amphimedon sp. 'blue-green' } \\
\text { Petrosiidae }\end{array}$ & Yes & Root & & & • \\
\hline На-са & Neopetrosia aff. carbonaria & Yes & Reef/rock & & & $\bullet$ \\
\hline Ne-ex & Neopetrosia exigua & Yes & Reef/rock & & & $\bullet$ \\
\hline Ha-bt & $\begin{array}{l}\text { Neopetrosia sp. 'blue' } \\
\text { Phloeodictyidae }\end{array}$ & Yes & Root & & & - \\
\hline Ak-mu & Aka mucosa & Yes & Sand & & & $\bullet$ \\
\hline \multirow[t]{2}{*}{ Oc-wh } & Oceanapia sp. 'white' & Yes & Sand & & & $\bullet$ \\
\hline & $\begin{array}{l}\text { POECILOSCLERIDA } \\
\text { Acarnidae }\end{array}$ & & & & & \\
\hline Ac-sp & $\begin{array}{l}\text { Acarnus sp. } \\
\text { Coelosphaeridae }\end{array}$ & No & Root/rock & & $\bullet$ & \\
\hline Bi-fo & Biemna fortis & Yes & $\begin{array}{l}\text { Root/mud/ } \\
\text { sand }\end{array}$ & $\bullet$ & $\bullet$ & $\bullet$ \\
\hline Li-sp & $\begin{array}{l}\text { Lissodendoryx aff. similis } \\
\text { Iotrochotidae }\end{array}$ & Yes & Root/rock & & $\bullet$ & \\
\hline Io-ba & $\begin{array}{l}\text { Iotrochota baculifera } \\
\text { Isodictyidae }\end{array}$ & Yes & Reef & & & $\bullet$ \\
\hline Co-si & $\begin{array}{l}\text { Coelocarteria singaporensis } \\
\text { Microcionidae }\end{array}$ & Yes & Sand & & & $\bullet$ \\
\hline An-th & Antho ridleyi & No & Root/rock & - & & \\
\hline \multirow[t]{2}{*}{ Cl-re } & Clathria reinwardti & Yes & $\begin{array}{l}\text { Rock/reef/ } \\
\text { sand }\end{array}$ & & & $\bullet$ \\
\hline & Raspailiidae & & & & & \\
\hline Ah-sp & Acanthostylotella cornuta & Yes & Rock & & $\bullet$ & \\
\hline Ec-sl & Echinodictyum conulosum & Yes & $\begin{array}{l}\text { Rock/reef/ } \\
\text { sand }\end{array}$ & & & $\bullet$ \\
\hline Ra-bl & Raspailia aff. bifurcata & Yes & Rock/sand & & $\bullet$ & $\bullet$ \\
\hline Ra-ye & $\begin{array}{l}\text { Raspailia aff. clathrata } \\
\text { Tedaniidae }\end{array}$ & No & Mud & $\bullet$ & & \\
\hline \multirow[t]{2}{*}{ Te-re } & Tedania diraphis & Yes & Root/rock & & & - \\
\hline & $\begin{array}{l}\text { SPIROPHORIDA } \\
\text { Tetillidae }\end{array}$ & & & & & \\
\hline Ci-au & Cinachyrella spp. & Yes & $\begin{array}{l}\text { Root/rock/ } \\
\text { mud/sand/ } \\
\text { reef }\end{array}$ & $\bullet$ & $\bullet$ & $\bullet$ \\
\hline \multirow[t]{2}{*}{$\mathrm{Pa}-\mathrm{cx}$} & Paratetilla bacca & Yes & $\begin{array}{l}\text { Root/rock/ } \\
\text { mud/sand/ } \\
\text { reef }\end{array}$ & - & - & - \\
\hline & $\begin{array}{l}\text { VERONGIDA } \\
\text { Ianthellidae }\end{array}$ & & & & & \\
\hline He-in & Hexadella aff. indica & No & Root/rock & $\bullet$ & & \\
\hline
\end{tabular}

The marine lake habitat provides a continuously sheltered and submerged environment with large sponges, while in contrast the coastal bay mangrove habitat, which is more exposed to waves and air at low tide, harbors smaller and fewer sponges (Figs. 2 \& 5). Sponges were patchily distributed in the coastal bay mangrove system, and some locations along the coast of Maratua and Kakaban did not contain a single sponge. This patchiness has frequently been noted in Caribbean mangroves and has been attributed in part to biotic factors, but mostly to abiotic environmental factors (e.g. Ellison \& Farnsworth 1992, Farnsworth \& Ellison 1996, Diaz et al. 2004, Wulff 2005, Hunting et al. 2008, Guerra-Castro et al. 2011). Exposure to currents was, for example, the most reliable predictor of percentage cover and diversity of species in Belize mangroves (Farnsworth \& Ellison 1996). Roots on protected coasts are typically dominated by massive sponges, ascidians, sea anemones, and fleshy algae, while the high-energy windward coasts are generally dominated by hydroids and filamentous algae with no sponges (Farnsworth \& Ellison 1996).

Each lake had distinct assemblages and these were significantly different from all transects in the coastal mangrove habitat of Maratua (Fig. 4A). However, even though the 2 marine lakes are separated by $10 \mathrm{~km}$, their assemblages were more similar to each other than to the coastal bay mangrove systems at just 200 to $500 \mathrm{~m}$ distance. The marine lakes harbored only a subset of the adjacent sea fauna. The difference in species composition between the lakes and the coastal mangroves can for a large part be attributed to both the nature of the barrier between the lake and sea (the putative source of the species pool) as well as to various environmental characteristics within the lake systems (Becking et al. 2011). Depending on the degree of connection to the sea, the lakes can more or less resemble a coastal lagoon in geomorphology and species assemblage. Kakaban and Haji Buang 
Table 2. Dominant mangrove genera and range in salinity, temperature, and $\mathrm{pH}$ in Kakaban Lake (KKB), Haji Buang Lake (HBL), and the outer coastal mangroves of Maratua Island (BAY). Measurements were taken in September 2008 and May 2009, range given was the same in each year

\begin{tabular}{|c|c|c|c|c|}
\hline Lake & $\begin{array}{c}\text { Salinity } \\
\text { (ppt) }\end{array}$ & $\begin{array}{l}\text { Tempera- } \\
\text { ture }\left({ }^{\circ} \mathrm{C}\right)\end{array}$ & $\mathrm{pH}$ & $\begin{array}{l}\text { Mangrove } \\
\text { genera }\end{array}$ \\
\hline KKB & $23-24$ & $29-32$ & $7.0-7.8$ & Bruguiera \\
\hline HBL & $26-28$ & $29-30$ & $7.3-7.8$ & Bruguiera \\
\hline BAY & $33-34$ & $28-32$ & $7.8-8.3$ & $\begin{array}{l}\text { Avicennia, } \\
\text { Rhizophora, } \\
\text { Sonneratia }\end{array}$ \\
\hline
\end{tabular}

lakes are highly isolated lakes following the classification of Becking et al. (2011). The substantially different environmental variables (salinity, $\mathrm{pH}$, degree of exposure to waves and air) as well as the different species of mangroves between both habitats are possibly forces that structure sponge composition (Table 2, Fig. 5). Salinity is lower in the lakes than in the adjacent coastal mangroves and coral reefs, which can be a limiting factor for sponges as well as many other coral reef organisms. Likewise, the coastal bay mangrove habitat has more extended periods of exposure to air, which only few sponge species can tolerate (Rützler 1995), while the lake basins remain submerged during all tidal phases. In the Caribbean, mangroves and coral reefs have been shown to differ substantially in composition (Ellison \& Farnsworth 1992, Farnsworth \& Ellison 1996, Wulff 2000, Diaz et al. 2004, Hunting et al. 2008, GuerraCastro et al. 2011). Species within the typical mangrove sponge community are specifically adapted to survive extremes in abiotic factors such as salinity, temperature, and sedimentation, either through tolerance or through rapid recovery after storms (Rützler 1995, Engel \& Pawlik 2005, Wulff 2005, Pawlik et al. 2007, Nagelkerken et al. 2008). Pawlik et al. (2007) observed that reef species declined in health and died within $60 \mathrm{~d}$ of being transplanted to mangrove sites. This result was attributed to the inability of reef species to tolerate the abiotic conditions of high temperature, rainfall events, and sedimentation in mangroves.

Lake and bay mangrove habitats shared only a few species and most of these shared species (e.g. Cinachyrella spp., Paratetilla bacca, Biemna fortis, Suberites diversicolor) are also known to occur in perturbed areas or extreme environments in the tropical Indo-Pacific (e.g. Hooper et al. 2002, McDonald et al. 2002, Cleary \& de Voogd 2007, 2009, de Voogd \& Cleary 2007, Becking \& Lim 2009). Though the lakes are minimally perturbed by human influence,
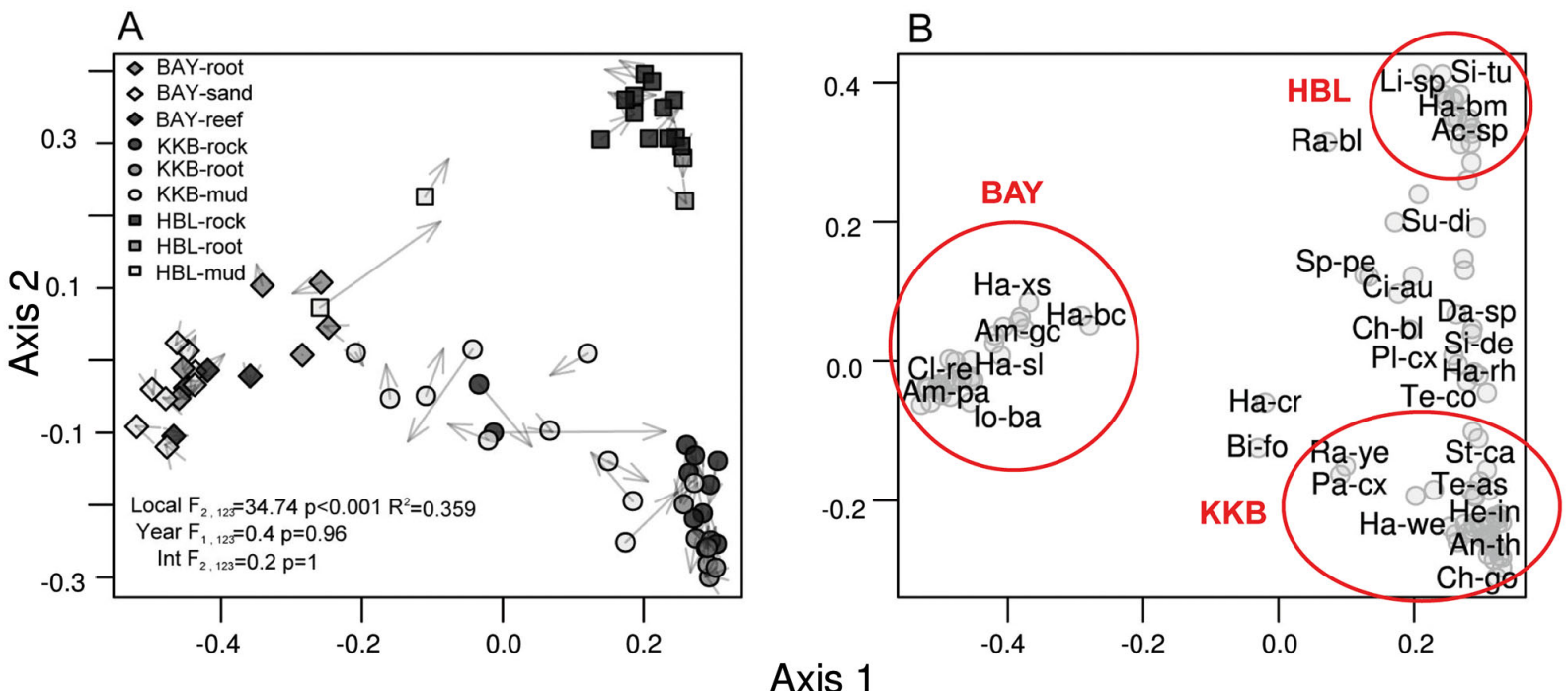

Fig. 4. Ordination scores of transects (A) and weighted averages scores of sponge species (B) along the first and second Principal Coordinates Analysis (PCO) axes representing variation in sponge community composition among substrate types (mud, rock, root, reef, and sand) in the locations Kakaban Lake (KKB), Haji Buang Lake (HBL) and the outer coastal mangroves of Maratua Island (BAY). Arrows in A represent temporal variation in composition from transects sampled in 2008 (symbols) to the same transects sampled in 2009 (arrow heads). In B, species are indicated by dots; selected species are indicated by codes following Table 1. The principal axis of variation represents variation from transects in marine lake habitats (KKB and HBL) to transects in bay mangroves. The secondary axis of variation (axis 2) is primarily related to variation between lake habitats. Note that mud transects from both lakes tend to exhibit the greatest similarity in composition with mangrove transects. Weighted averages scores of sponge species was estimated using the wascores function of the vegan library in R and based on the first 2 PCO ordination axes. Results of adonis tests are given in the bottom left of A 

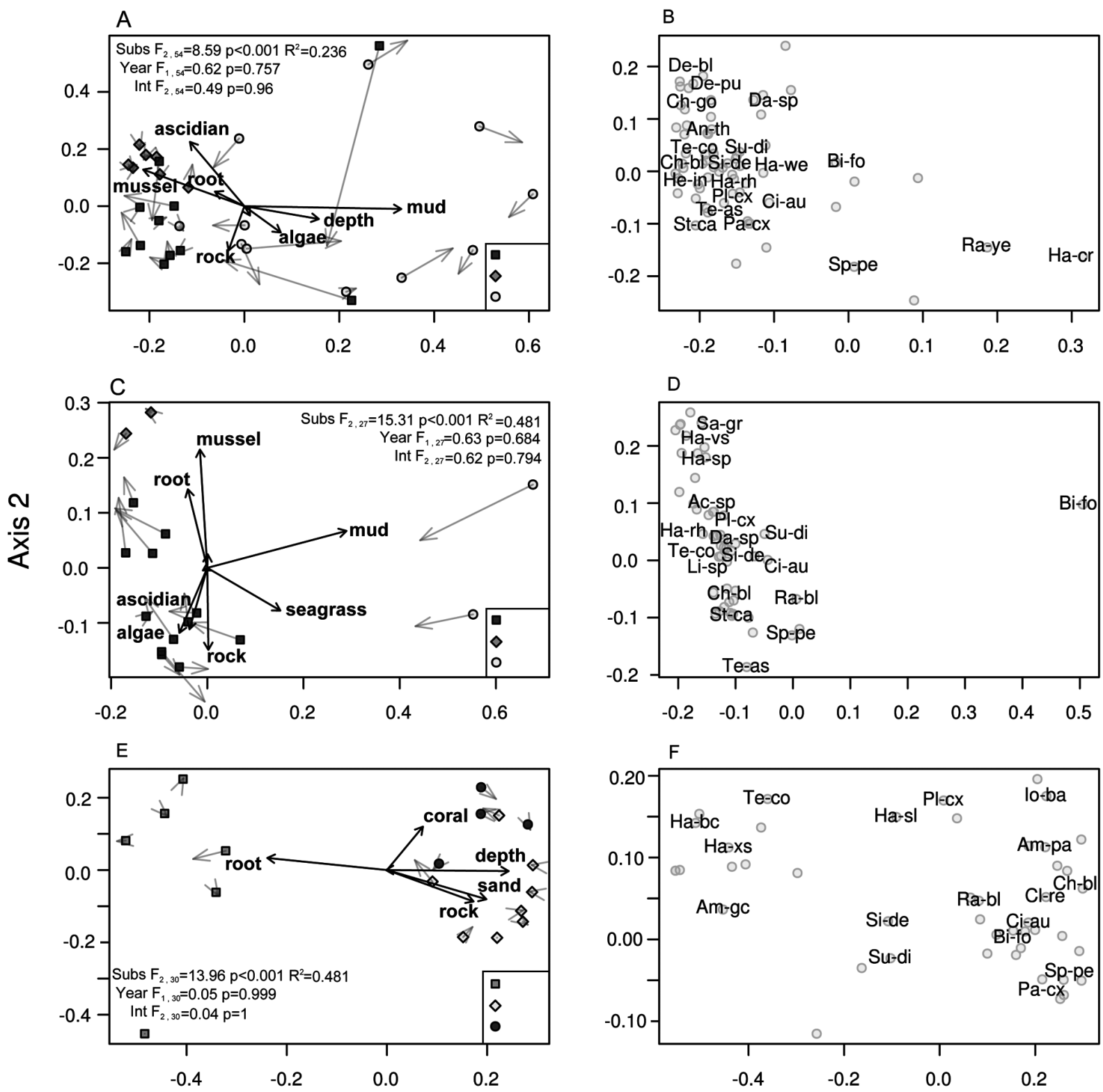

\section{Axis 1}

Fig. 5. Ordination scores of transects and weighted averages scores of sponge species along the first and second Principal Coordinates Analysis (PCO) axes for (A,B) Kakaban Lake (KKB), (C,D) Haji Buang Lake (HBL) and (E,F) coastal mangroves of Maratua Island (BAY). Transects on different substrate types (mud, rock, root, reef, and sand) are indicated by symbols. Codes in B, D and F represent sponge species following Table 1. Grey arrows represent temporal variation in composition from transects sampled in 2008 (symbols) to the same transects sampled in 2009 (arrowheads of grey arrows). Black arrows are vectors of environmental variables (cover of ascidians, mussels, mud, seagrass, bare rock, bare root, and coral in transect, depth of transect) representing maximal correlations with the ordination configuration obtained using the envfit function in the vegan library in $\mathrm{R}$. The principal axis of variation (axis 1) represents variation among solid and soft substrate. Results of adonis tests are given in the corners of $\mathrm{A}, \mathrm{C}$ and $\mathrm{E}$

they do share some characteristics with perturbed coastal environments, such as high turbidity and low salinity. The majority of sponge species in the coastal bay mangrove habitat are common, widely distributed, and have been recorded in tropical sheltered bays, sandy reef flats, or coral reefs across Indonesia (e.g. Becking et al. 2006, de Voogd \& Cleary 2008, 2009, de Voogd et al. 2009). In contrast, a large portion of the species in the lakes was not known from any published records of the reefs; many are undescribed species and new to science. The majority of the lake specific species were from the families Chali- 

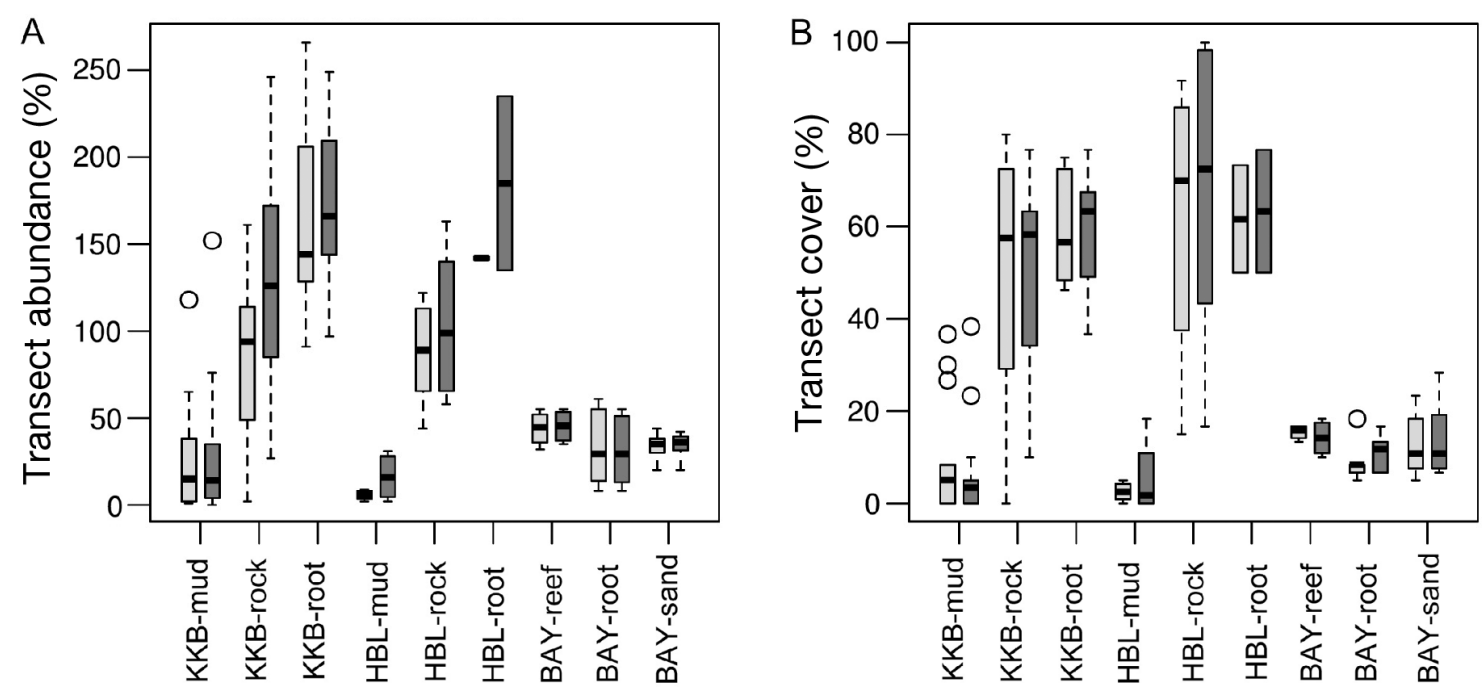

Fig. 6. Box-and-whisker plots of (A) the abundance and (B) the cover of sponges across locations Kakaban Lake (KKB), Haji Buang Lake (HBL), and coastal mangroves of Maratua Island (BAY), and substrate types (mud, rock, root, reef, and sand). Light grey represents data from 2008 and dark grey represents data from 2009. The thick black line intersecting each boxplot represents the median value. The boxes show the first and third quartiles. Open circles represent outliers, and the upper and lower whiskers represent the most extreme data point that is no more than 1.5 times the interquartile range from the box (graph created using the default values for the boxplot function in R). See Table 3 for adonis results

nidae, Darwinellidae, Dictyodendrillidae, and Tethyidae. In Caribbean mangroves, the Chalinidae is generally also the most speciose family (e.g. de Weerdt 2000, Diaz et al. 2004, Wulff 2004, Guerra-Castro et al. 2011). The species of Darwinellidae, Dictyodendrillidae, and Tethyidae occurred in high abundances and the individuals were often large. In contrast, few species belonging to these families have been observed in the reefs of Indonesia and the ones that do occur are always small and found in low abundance (e.g. de Voogd \& Cleary 2008, de Voogd et al. 2009).

The marine lakes of Berau were formed less than 15000 yr ago (Sathiamurthy \& Voris 2006), yet they contain species that are not known from any other location. Both Kakaban and Haji Buang lakes had species that were only recorded in one lake and possibly represent local endemics. In Kakaban Lake, half the species recorded were restricted to this lake. Many rare and novel genera and species among a variety of taxa have been described from this highly isolated lake, such as a crab (Orcovita saltatrix), 2 holothurians (Holothuria cavans and Synaptula spinifera), and an ascidian (Styela complexa) ( $\mathrm{Ng} \&$ Tomascik 1994, Tomascik \& Mah 1994, Massin \& Tomascik 1996). It is nevertheless possible that these 'endemic' lake-dwelling sponge species with large growth forms may occur elsewhere in cryptic locations such as crusts in reefs or marine caves, and may thus have been overlooked during reef surveys

Table 3. Results of adonis tests of variation in abundance and cover of sponges among substrate and year across locations Kakaban Lake (KKB), Haji Buang Lake (HBL), and the outer coastal mangroves of Maratua Island (BAY)

\begin{tabular}{|c|c|c|c|c|c|c|c|c|c|}
\hline & \multicolumn{3}{|c|}{ Substrate } & \multicolumn{3}{|c|}{ Year } & \multicolumn{3}{|c|}{ Interaction } \\
\hline & $\mathrm{df}$ & $F$ & $\mathrm{p}$ & df & $F$ & $\mathrm{p}$ & $\mathrm{df}$ & $F$ & $\mathrm{p}$ \\
\hline \multicolumn{10}{|c|}{ Abundance } \\
\hline KKB & 2,54 & 28.70 & $<0.001$ & 1,54 & 1.18 & 0.252 & 2,54 & 0.84 & 0.419 \\
\hline HBL & 2,26 & 21.64 & $<0.001$ & 1,26 & 2.48 & 0.132 & 2,26 & 0.30 & 0.738 \\
\hline BAY & 2,30 & 2.33 & 0.129 & 1,30 & 0.00 & 1.000 & 2,30 & 0.04 & 0.960 \\
\hline \multicolumn{10}{|c|}{ Cover } \\
\hline KKB & 2,54 & 43.89 & $<0.001$ & 1,54 & 0.64 & 0.252 & 2,54 & 0.02 & 0.984 \\
\hline HBL & 2,26 & 10.28 & $<0.001$ & 1,26 & 0.36 & 0.557 & 2,26 & 0.02 & 0.990 \\
\hline BAY & 2,30 & 1.65 & 0.214 & 1,30 & 0.00 & 0.647 & 2,30 & 0.18 & 0.829 \\
\hline
\end{tabular}


(Pawlik 1998). We did, however, thoroughly scrutinize the coastal coral reefs, mangroves, and sandy reef flats in search of these lake species.

To summarize, the lake assemblages contained 3 groups of species: (1) species that are widely distributed (e.g. Cinachyrella spp. and Placospongia spp.); (2) species that are shared by both lakes and that have been observed in other Indo-Pacific lakes (e.g. Darwinella aff. gardineri and Tethytimea aff. tylota); and (3) species that have (thus far) only been observed in a single lake (e.g. several species of the genus Haliclona). The only representative study of sponge fauna in marine lakes in the Indo-Pacific so far was conducted in Ha Long Bay in Vietnam (Cerrano et al. 2006, Azzini et al. 2007). The Indonesian and Vietnamese marine lakes share few species, though similar patterns in assemblage structures are seen in both. A qualitative survey of species presence and absence on the rocky shore within lakes and adjacent coastal habitats in Vietnam revealed that the more isolated lakes harbored unique species; 23 species (out of a total of 63) were only present in the lakes, 18 of these were only observed in a single lake. In the lakes of Vietnam, there is a wide variation in the degree of connection to the sea. The wellconnected lakes harbored coral and sponge assemblages that did not differ from those in adjacent bays, while the more isolated lakes had much less compositional overlap (Azzini et al. 2007). The mangrove fringed ponds of the Pelican Cays in Belize, though not anchialine systems, show some similarities to Indo-Pacific marine lakes. Comparison of the sponge fauna in these ponds with more common open mangrove systems indicated that the ponds contained a distinct species assemblage with a high number of rare and undescribed taxa (Rützler et al. 2000).

\section{Differences among substrates}

In all habitats there was a clear zonation away from the shoreline. In the marine lakes, the hard substrates such as rock and root along the coast harbored multitudes of sponges, while the abundance, cover, and number of species declined markedly with just 1 to $2 \mathrm{~m}$ distance from the shore in the soft flocculent mud substrate (Fig. 6). Mud and sediments can clog the oscula and pores of sponges, which can adversely affect their pumping (Gerrodette \& Flechsig 1979) Certain species have adapted their morphology to circumvent these negative effects, for example, by means of psammobiontic growth forms (e.g. Biemna fortis) or a hairy-bristly surface which can capture fine sediments (Paratetilla bacca, Cinachyrella spp, and Raspaillia spp.). In our study, root, mussel, ascidian, and algae cover was strongly related to variation in sponge composition in both lakes. Roots almost always had a high cover of mussels, while the cover of mussels on rock substrates was much lower (or absent as was the case in Haji Buang lake). The relationship between mussel cover and sponge composition may therefore be simply correlative and not due to spatial competition or other inter-taxon interactions. Algae occurred on roots in Kakaban lake, but increased dramatically to almost $100 \%$ cover with depth in the more muddy substrates. In Haji Buang lake, the subtidal quadrats could be covered $100 \%$ by algae that formed a blanket over a high sponge cover underneath. Remarkably this covering did not seem to adversely affect the sponges. More detailed research, however, is needed to understand how the various benthic taxa within marine lakes interact.

Within both habitats (marine lakes and coastal mangroves) sponge species composition differed markedly between mangrove roots and other substrates with certain species only occurring on mangrove roots. In Haji Buang lake, there were only 2 transects in the mangrove roots (due to limited mangrove cover in this lake), yet these assemblages contained species that were not present in the remainder of the lake. Differential response of sponge larvae to concentration of tannins in mangrove roots may play a role in structuring the assemblages associated with mangroves (Hunting et al. 2008, 2010). The ability to resist tidal exposure may, furthermore, be a strong selective trait for species survival in mangrove systems. The most speciose order associated with roots in the lakes and bay mangroves is composed of the Haplosclerida, particularly the family Chalinidae, and within that the genus Haliclona. The majority of Haliclona spp. were recorded as exposed to air during low tide. Many Caribbean Haliclona spp. can tolerate strong water movement, sudden oscillations in temperature and salinity, as well as exposure to air (de Weerdt et al. 1991, de Weerdt 2000). Certain Haliclona spp. are able to resist desiccation, including $4 \mathrm{~h}$ of exposure to sun, by being able to retain more water during exposure to sun than deeper water species (Rützler 1995).

\section{Variation between sampling events}

Sponge species composition, abundance, and cover in marine lakes and coastal mangroves in Indonesia 
did not vary significantly between sampling events in 2008 and 2009. Some individual transects did exhibit differences in composition between sampling events, but there was little evidence of a strong and consistent change in composition across sites over a longer time period (>6 mo) based on the ordinations as indicated in Figs. 3 \& 4 . Our lack of directional change differs somewhat from results obtained in Vietnamese marine lakes, where degeneration of species and subsequent variation in local assemblages was observed after 6 mo and longer due to heightened temperature and extreme rainfall during the monsoon season (Cerrano et al. 2006, Azzini et al. 2007). Our contrasting results with Vietnam may be due to the fact that seasonal differences are much less pronounced in Berau than in Vietnam. However, longer-term monitoring is necessary to gain a fuller understanding of sponge community dynamics in marine lake environments.

\section{Sponges in Indo-Pacific mangroves}

This is the first study to illustrate that mangroves in the Indo-Pacific can harbor a diverse array of sponge species. The number of sponge species associated with mangroves recorded for the Caribbean (scale of $1000 \mathrm{~s}$ of $\mathrm{km}$ ) is just under 150 based on papers from the 1960s up until now (e.g. Rützler 1969, Diaz et al. 2004, Guerra-Castro et al. 2011). In only a single study at a much smaller scale $(10 \mathrm{~km})$, we recorded a total of 115 sponge species in the marine lakes and coastal mangroves of Berau, of which 74 species were attached to mangrove roots. A large portion of the Indonesian coastline is fringed by a great diversity of mangrove species (Spalding et al. 1997, Alongi 2002) that have yet to be explored for epibionts. In recent years, over 45 marine lakes that are new to science have been discovered in the Raja Ampat Islands, Indonesia (Becking et al. 2011, L. E. Becking pers. obs.). As such, a vast amount of diversity remains to be unveiled in Indonesia, and probably beyond in the wider Indo-Pacific. The unique habitat and species composition of marine lakes warrants further study and conservation.

Acknowledgements. Bahruddin, Estradivari, N. Santodomingo, E. Dondorp, and W. Renema were invaluable sources of information and help in the field. We also thank the following people for their help in various ways: B. Hoeksema, Suharsono, Y. Tuti, E. Oberhauser, R. Suhr, and the staff of TNC/World Wildlife Foundation (WWF) Berau Office, Nabucco Island Dive Resort, and of Derawan Dive Resort. This study is part of a $\mathrm{PhD}$ project (L.E.B.) funded by
NWO, division Earth and Life Sciences (ALW IPJ-07002; \# 817.01.008). Fieldwork in Indonesia was made possible through additional financial support of WWF NetherlandsINNO Fund, the Schure-Beijerinck-Popping Fund of the Royal Dutch Academy of Science (KNAW), the TreubMaatschappij Fund, The Netherlands WWF-INNO Subsidy, the Leiden University Fund (LUF)/Slingelands, Singapore Airlines, the A.M. Buitendijk Fund and the J.J. ter Pelkwijk Fund (NCB Naturalis). D.F.R.C. was supported by the Portuguese Foundation for Science and Technology, FCT, project LESS CORAL, PTDC/AAC-AMB/115304/2009. We are grateful to the Indonesian Institute of Sciences (LIPI) and the Indonesian State Ministry of Research and Technology (RISTEK) for providing research permits in Indonesia. R. van Soest, B. Hoeksema, and 4 anonymous reviewers provided valuable comments on the original manuscript.

\section{LITERATURE CITED}

Aerts LAM, van Soest RWM (1997) Quantification of sponge/ coral interactions in a physically stressed reef community, NE Colombia. Mar Ecol Prog Ser 148:125-134

- Alongi DM (2002) Present state and future of the world's mangrove forests. Environ Conserv 29:331-349

Azzini F, Calcinai B, Cerrano C, Bavestrello G, Pansini M (2007) Sponges of the marine karst lakes and of the coast of the islands of Ha Long Bay (north Vietnam). In: Custodia MR, Lobo-Hajdu G, Hajdu E, Muricy G (eds) Porifera research: biodiversity, innovation and sustainability. Série Livros 28. Museu Nacional, Rio de Janeiro, p 157-164

> Barnes DKA (1999) High diversity of tropical intertidal zone sponges in temperature, salinity and current extremes. Afr J Ecol 37:424-434

Becking LE, Lim SC (2009) A new Suberites (Demospongiae: Hadromerida: Suberitidae) from the tropical IndoWest Pacific. Zool Meded 83:853-862

Becking LE, Cleary DFR, de Voogd NJ, Renema W, de Beer M, van Soest RWM, Hoeksema BW (2006) Beta diversity of tropical marine benthic assemblages in the Spermonde Archipelago, Indonesia. PSZN I: Mar Ecol 27:76-88

> Becking LE, Renema W, Santodomingo NK, Hoeksema BW, Tuti Y, de Voogd NJ (2011) Recently discovered landlocked basins in Indonesia reveal high habitat diversity in anchialine systems. Hydrobiologia 677:89-105

Becking LE (in press) Revision of the genus Placospongia (Porifera: Hadromerida: Placospongiidae) in the IndoWest Pacific. Zookeys

> Bingham BL, Young CM (1995) Stochastic events and dynamics of a mangrove root epifaunal community. PSZN I: Mar Ecol 16:145-163

> Blanchet FG, Legendre P, Borcard D (2008) Forward selection of explanatory variables. Ecology 89:2623-2632

> Borcard D, Legendre P (2002) All-scale spatial analysis of ecological data by means of principal coordinates of neighbour matrices. Ecol Model 153:51-68

> Boury-Esnault N, Rützler K (1997) Thesaurus of sponge morphology. Smithson Contrib Zool 596:1-55

> Cerrano C, Azzini F, Bavestrello G, Calcinai B, Pansini M, Sarti M, Thung DC (2006) Marine lakes of karst islands in Ha Long Bay (Vietnam). Chem Ecol 22:489-500

> Cleary DFR (2003) An examination of scale of assessment, logging and ENSO-induced fires on butterfly diversity in Borneo. Oecologia 135:313-321 
Cleary DFR, de Voogd NJ (2007) Environmental associations of sponges in the Spermonde Archipelago, Indonesia. J Mar Biol Assoc UK 87:1669-1676

Cleary DFR, Becking LE, de Voogd NJ, Renema W, de Beer M, van Soest RWM, Hoeksema BW (2005) Variation in the diversity and composition of benthic taxa as a function of distance offshore, depth and exposure in the Spermonde Archipelago, Indonesia. Estuar Coast Shelf Sci 65:557-570

Colin PL (2009) Marine environments of Palau. Indo-Pacific Press, San Diego, CA

> Dawson MN, Hamner WM (2005) Rapid evolutionary radiation of marine zooplankton in peripheral environments. Proc Natl Acad Sci USA 102:9235-9240

Dawson MN, Martin LE, Bell LJ, Patris S (2009) Marine lakes. In: Gillespie R, Clague DA (eds) Encyclopedia of islands. University of California Press, Berkeley, CA, p 603-607

de Voogd NJ, Cleary DFR (2007) Relating species traits to environmental variables in Indonesian coral reef sponge assemblages. Mar Freshw Res 58:240-249

de Voogd NJ, Cleary DFR (2008) An analysis of sponge diversity and distribution at three taxonomic levels in the Thousand Islands/Jakarta Bay reef complex, West-Java, Indonesia. PSZN I: Mar Ecol 29:205-215

de Voogd NJ, Cleary DFR (2009) Variation in sponge composition among Singapore reefs. Raffles Bull Zool Suppl 22:59-67

de Voogd NJ, Becking LE, Noor A, Hoeksema BW, van Soest RWM (2004) Sponge interactions with spatial competitors in SW Sulawesi. Boll Mus Ist Biol Univ Genova 68: 253-261

> de Voogd NJ, Cleary DFR, Hoeksema BW, Noor A, van Soest RWM (2006) Sponge beta diversity in the Spermonde Archipelago, SW Sulawesi, Indonesia. Mar Ecol Prog Ser 309:131-142

de Voogd NJ, Becking LE, Cleary DFR (2009) Sponge community composition in the Derawan Islands, NE Kalimantan, Indonesia. Mar Ecol Prog Ser 396:169-180

de Weerdt WH (2000) A monograph of the shallow water Chalinidae (Porifera, Haplosclerida) of the Caribbean. Beaufortia 50:1-67

de Weerdt WH, Rützler K, Smith KP (1991) The Chalinidae (Porifera) of Twin Cays, Belize, and adjacent waters. Proc Biol Soc Wash 104:189-205

Diaz MC (2005) Common sponges from shallow marine habitats from Bocas del Toro region, Panama. Caribb J Sci 41:465-475

Diaz MC, Smith KP, Rützler K (2004) Sponge species richness and abundance as indicators of mangrove epibenthic community health. Atoll Res Bull 518:1-17

> Dray S, Legendre P, Peres-Neto PR (2006) Spatial modelling: A comprehensive framework for principal coordinate analysis of neighbour matrices (PCNM). Ecol Model 196: 483-493

> Ellison AM, Farnsworth EJ (1992) The ecology of Belizean mangrove-root fouling communities: patterns of epibiont distribution and abundance, and effects on root-growth. Hydrobiologia 247:87-98

Ellison AM, Farnsworth EJ, Twilley RR (1996) Facultative mutualism between red mangroves and root-fouling sponges in Belizean mangal. Ecology 77:2431-2444

Engel S, Pawlik JR (2005) Interactions among Florida sponges. II. Mangrove habitats. Mar Ecol Prog Ser 303: 145-152
Farnsworth EJ, Ellison AM (1996) Scale-dependent spatial and temporal variability in biogeography of mangrove root epibiont communities. Ecol Monogr 66:45-66

Fransen CHJM, Tomascik T (1996) Parhippolyte uveae Borradaille, 1899 (Crustacea: Decapoda: Hippolytidae) from Kakaban Island, Indonesia. Zool Meded 70:227-233

> Gerrodette T, Flechsig AO (1979) Sediment-induced reduction in the pumping rate of the tropical sponge Verongia lacunosa. Mar Biol 55:103-110

Guerra-Castro E, Young P, Perez-Vazquez A, Carteron S, Alvizu A (2011) Spatial variability and human disturbance of sponge assemblages associated with mangrove roots in the southern Caribbean. Mar Freshw Res 62: 491-501

Hamner WM, Hamner PP (1998) Stratified marine lakes of Palau (western Caroline Islands). Phys Geogr 19:175-220

Hoeksema BW (2004) Marine biodiversity of the coastal area of the Berau region, East Kalimantan, Indonesia: progress report East Kalimantan program-pilot phase (October 2003). Naturalis, Leiden

Holthuis LB (1973) Caridean shrimps found in land-locked saltwater pools at four Indo-West Pacific localities (Sinai Peninsula, Funafuti Atoll, Maui and Hawaii islands), with the description of one new genus and four new species. Zool Verh 128:1-48

Hooper JNA, Kennedy JA, Quinn RJ (2002) Biodiversity 'hotspots', patterns of richness and endemism, and taxonomic affinities of tropical Australian sponges (Porifera). Biodiversity Conserv 11:851-885

Hunting ER, van Soest RWM, van der Geest HG, Vos A, Debrot AO (2008) Diversity and spatial heterogeneity of mangrove associated sponges of Curacao and Aruba. Contrib Zool 77:205-215

- Hunting ER, van der Geest HG, Krieg AJ, van Mierlo MBL, van Soest RWM (2010) Mangrove-sponge associations: a possible role for tannins. Aquat Ecol 44:679-684

Legendre P, Gallagher ED (2001) Ecologically meaningful transformations for ordination of species data. Oecologia 129:271-280

Maciolek J (1983) Distribution and biology of Indo-Pacific insular hypogeal shrimps. Bull Mar Sci 33:606-618

Mantel S (2001) Berau model forest area. Environmental datasets and maps: land systems inventory. Consultancy Report, Indonesian Ministry of Forestry, Jakarta

Massin C, Tomascik T (1996) Two new holothurians (Echinodermata: Holothuroidea) from an anchialine lagoon of an uplifted atoll, Kakaban Island, East Kalimantan, Indonesia. Raffles Bull Zool 44:157-172

McDonald JI, Hooper JNA, McGuinness KA (2002) Environmentally influenced variability in the morphology of Cinachyrella australiensis (Carter 1886) (Porifera: Spirophorida: Tetillidae). Mar Freshw Res 53:79-84

> Nagelkerken I, Blaber SJM, Bouillon S, Green P and others (2008) The habitat function of mangroves for terrestrial and marine fauna: a review. Aquat Bot 89:155-185

Ng PKL, Tomascik T (1994) Orcovita saltatrix, a new genus and species of anchialine varunine crab (Crustacea, Decapoda, Brachyura, Grapsidae) from Kakaban Island, Indonesia. Raffles Bull Zool 42:937-948

Oksanen J, Guillaume Blanche F, Kindt R, Legendre P and others (2009) Vegan: community ecology package. R package version 1.15-4, available at http://cran.R-project. Org/package=vegan

Pawlik JR (1998) Coral reef sponges: Do predatory fishes affect their distribution? Limnol Oceanogr 43:1396-1399 
Pawlik JR, McMurray SE, Henkel TP (2007) Abiotic factors control sponge ecology in Florida mangroves. Mar Ecol Prog Ser 339:93-98

Renema W (2006) Habitat variables determining the occurrence of large benthic foraminifera in the Berau area (East Kalimantan, Indonesia). Coral Reefs 25:351-359

Rützler K (1964) Aspects of littoral life in the Indian Ocean. Atti Semin Stud Biol 1:1-17

Rützler K (1969) The mangrove community: aspects of its structure, faunistics, and ecology. In: Memorias, Simposio International Lagunas Costeras, 1967, UNAM, 53, Mexico, D.F, p 515-536

Rützler K (1995) Low-tide exposure of sponges in a Caribbean mangrove community. PSZN I: Mar Ecol 16: 165-179

Rützler K, Diaz MC, van Soest RWM, Zea S, Smith KP, Alvarez B, Wulff J (2000) Diversity of sponge fauna in mangrove fringed ponds, Pelican Cays, Belize. Atoll Res Bull 467:229-248

Sasekumar A, Chong VC (1998) Faunal diversity in Malaysian mangroves. Global Ecol Biogeogr Lett 7:57-60

Sathiamurthy E, Voris HK (2006) Maps of Holocene sea level transgression and submerged lakes on the Sunda shelf. Nat Hist J Chulalongkorn Univ 2(Suppl.):1-44

Spalding M, Blasco F, Field C (1997) World mangrove atlas. International Society for Mangrove Ecosystems, Okinawa

Editorial responsibility: Joseph Pawlik, Wilmington, North Carolina, USA
Sutherland JP (1980) Dynamics of the epibenthic community on roots of the mangrove Rhizophora mangle, at Bahia de Buche, Venezuela. Mar Biol 58:75-84

Szitenberg A, Becking LE, Vargas S, Fernandez JCC and others (2013) Phylogeny of Tetillidae (Porifera, Demospongiae, Spirophorida) based on three molecular markers. Mol Phylogen Evol 67:509-519

Tomascik T, Mah AJ (1994) The ecology of 'Halimeda lagoon': an anchialine lagoon of a raised atoll, Kakaban Island, East Kalimantan, Indonesia. Trop Biodiversity 2: 385-399

Tomascik T, Mah AJ, Nontji A, Moosa MK (1997). The ecology of the Indonesia Seas. Part II. Periplus, Tuttle Publishing, Singapore

Wulff JL (2000) Sponge predators may determine difference in sponge fauna between two sets of mangrove cays, Belize Barrier Reef. Atoll Res Bull 477:251-263

Wulff JL (2004) Sponges on mangrove roots, Twin Cays, Belize: early stages of community assembly. Atoll Res Bull 519:1-10

Wulff JL (2005) Trade-offs in resistance to competitors and predators, and their effects on the diversity of tropical marine sponges. J Anim Ecol 74:313-321

Wulff JL (2010) Regeneration of sponges in ecological context: Is regeneration an integral part of life history and morphological strategies? Integr Comp Biol 50:494-505

Submitted: October 10, 2012; Accepted: November 1, 2012 Proofs received from author(s): April 12, 2013 